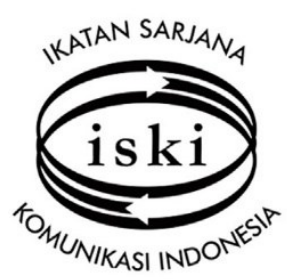

J U R R N A L

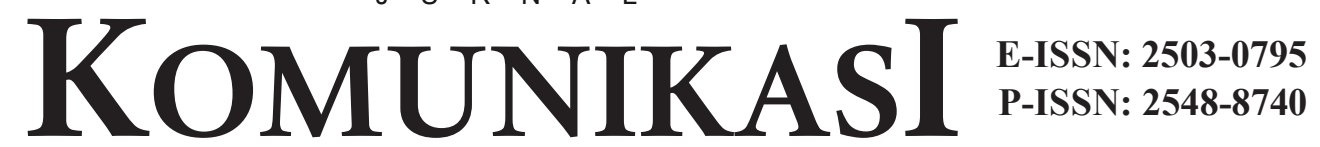

IKATANSARJANAKOMUNIKASI INDONESIA

https://doi.org/10.25008/jkiski.v4i2.328

\title{
Oligarchic Media Ownership and Polarized Television Coverage in Indonesia's 2014 Presidential Election
}

\author{
Prasakti Ramadhana Fahadi ${ }^{*}$ \\ ${ }^{1}$ Department of Communication Science, Universitas Gadjah Mada \\ Jl. Socio Justicia I, Bulaksumur, Sleman, Yogyakarta - Indonesia \\ *Corresponding author's email: prasakti.r.f@ugm.ac.id
}

Submited: 09 August 2019, Revised: 14 September 2019, Accepted: 20 September 2019

Accredited by Kemristekdikti No. 28/E/KPT/2019

\begin{abstract}
It has been argued that the media ownership is an influential factor determining the content production and performance of the media. However, knowledge about the characteristics of the media ownership and its impacts on the coverage of general election by the media has been less researched. Judging by such developments, this work raises the following question: how did the oligarchic ownership of the Indonesian news television channels determine the ways in which they covered two candidates who ran for president in 2014? By selecting TV One and Metro TV as a case study, this work extracts reports on the ways in which these news TV channels have produced news content related to the 2014 general election using qualitative and thematic content analyses. The findings are as follows: In the 2014 Indonesian presidential election, both TV One and Metro TV failed to comply with the ideal journalistic principles of covering both sides, objective and balanced reporting, as required by the Indonesian Broadcasting Commission, while broadcasting news about the two presidential candidates. Instead, the television stations preferred to broadcast the polarized news coverage of the presidential candidates. TV One appeared to show more support for the Prabowo-Hatta Rajasa presidential candidate pair, while Metro TV favoured the Joko Widodo-Jusuf Kalla presidential candidate pair. This suggests that oligarchic media ownership strongly influenced the content production and performance of these news TV channels. They were used by oligarchs who have the media company to convey their personal political agendas in the hope that it will influence, or even set, the public's agenda.
\end{abstract}

Keywords: Indonesian presidential election, polarized coverage, oligarchy, media ownership, agenda-setting and news television channel

\begin{abstract}
Abstrak
Gagasan kepemilikan media adalah faktor berpengaruh yang menentukan produksi dan penampilan media produksi telah banyak diusulkan. Akan tetapi, pengetahuan tentang sifat kepemilikan media dan dampaknya terhadap liputan pemilihan umum yang dilakukan oleh media masih kurang ditelaah. Dengan mempertimbangkan perkembangan tersebut, penelitian ini ingin mengajukan pertanyaan: bagaimana kepemilikan oligarkis saluran televisi berita Indonesia menentukan cara media tersebut meliput dua kandidat presiden yang mencalonkan diri untuk posisi presiden Indonesia 2014? Memilih TV One dan Metro TV sebagai studi kasus, penelitian ini mengekstraksi laporan mengenai cara saluran TV berita ini menghasilkan konten berita terkait pemilu 2014 menggunakan analisis konten kualitatif dan tematis. Temuannya adalah sebagai berikut: dalam acara Pemilihan Presiden Indonesia 2014, TV One dan Metro TV gagal mematuhi prinsip-prinsip jurnalistik yang ideal seperti
\end{abstract}


mencakup kedua belah pihak, obyektif, dan seimbang, seperti yang diberlakukan oleh Komisi Penyiaran Indonesia, ketika menyiarkan berita tentang dua kandidat presiden. Sebaliknya, stasiun televisi lebih suka menyajikan liputan berita terpolarisasi pada kandidat presiden. TV One menunjukkan lebih banyak dukungan untuk kandidat Presiden-Wapres Prabowo-Hatta Rajasa, sementara Metro TV untuk Joko Widodo-Jusuf Kalla. Ini menunjukkan, kepemilikan media oligarkis sangat memengaruhi produksi dan kinerja konten oleh saluran TV berita ini. Mereka digunakan oleh pelaku-pelaku oligarki yang memiliki perusahaan media untuk menyampaikan agenda politik pribadi mereka dengan harapan hal itu akan mempengaruhi, atau bahkan menetapkan, agenda publik.

Keywords: Pemilihan umum presiden RI, Polarisasi liputan, Oligarki, Kepemilikan media, Agenda setting dan saluran televisi berita

\section{Introduction}

Television remains to be a popular mass media product amongst Indonesians. It has a penetration rate of up to 90 percent out of the total population (Utomo, 2017). When it comes to monitoring the national politics, television is still a top choice next to newspaper and digital media (Idrus, 2018). One of the reasons is that television is more up-to-date with information distribution than print media but it is much more accessible to many people than online media. Even it is more relevant when applied to monitoring national election, especially presidential election: an event with nationwide impact that the public demand to be kept continuously updated with the latest information.

The Indonesia Broadcasting Commission's Broadcasting Practice Guideline and Broadcasting Program Regulations stipulate that all television stations using public frequency must stay politically neutral and well-balanced when airing a news coverage, for the sake of the public's interests. Additionally, they must cover both sides of the story every time they report or cover an event (KPI, 2012). However, in Indonesia's 2014 Presidential Election, TV One and Metro TV, which use public frequency chose to disregard this regulation by airing rather polarized coverage of the two presidential candidates. TV One broadcast in favour of the Prabowo-Hatta Rajasa pair, while Metro TV showed more support for the Joko Widodo-Jusuf Kalla pair.

Judging by the developments, this work raises the following question: how did the oligarchic ownership of the Indonesian news TV channels determine the ways in which they covered the two candidates who run for president in 2014? Focusing on this question, this work contends that the culture of oligarchic media ownership in Indonesia is an influential factor that determines the ways in which media events are covered, such as the presidential candidates since they stepped into the 2014 presidential election race.
In his work Indonesian News TV Channels and Polarized Political Issues, Nyarwi Ahmad mentioned Indonesian Media in the Post-Soeharto regime. He then elaborated the polarization of the political issues in the 2019 Indonesian Presidential Election. In response to that, this article is aimed to explore a different focus of polarization by emphasizing the oligarchic culture within the said media system through an observation of the 2014 Presidential Election. It will furthermore provide an alternative analysis of the political polarization trend throughout the Indonesian Presidential Election season in the past ten years. It is also deemed to be important to track and monitor the social, cultural, political and economic dynamics affected by this culture. Using agenda-setting theory and framing function of media, it adopts a case study method to draw conclusions about the production culture, readership and economic, technological and political constraints operating on the media and also Indonesia in general. A detailed analysis of television news coverage, particularly by TV One and Metro TV, of 2014 Presidential Election of Indonesia will be chronicled. First, however, it will be valuable to discuss definitions and introduce some background to the Indonesian media.

\section{Theoretical Framework}

\section{Indonesian oligarchic media ownership}

Oliver Worth refers to the term oligarch as a group of individuals who are primarily concerned with economic expansion and dominance instead of political power (2017). Similarly, Jeffrey A. Winters explains the definition of oligarch as actor(s) “...who command and control massive concentrations of material resources that can be deployed to defend or enhance their personal wealth and exclusive social position" (Winters, 2011). Contextually amongst Russian society, an oligarch can also be someone who has sufficient control over resources, and therefore, they can be politically influential 
(Melander, 2010). In the US, Donald Trump could be considered to an embodiment of an oligarch. In the Central and Eastern European (CEE) countries, the oligarchization of their media ownership began in 2010, when Western investors started to gradually back out of CEE (Stetka, 2016).

The oligarchic system in the Indonesian media is a legacy left by the authoritarian era of New Order. The New Order is a term used to characterize Indonesia's second president, Soeharto's regime as he rose to power in 1966. It is then used to address the era of his presidency (1966-1998). During this period of time, the Indonesian media was completely under the government's control.

There used to be only one TV station, Televisi Republik Indonesia or TVRI. TVRI is now known as a public television channel or station, but during Soeharto's regime, 'government television channel' would have been a more proper title. In the past, TVRI was used by the government to shape viewers' nationalism mentality. It was also used to convince people of how great the government was and why they needed to continue to elect Soeharto as their president (Steele, 2011). As illustrated in the article Reading the Movement of Television by Indonesian independent communication and media studies center, RemoTivi, the government used to utilize this channel to slowly shape a nationalism mindset amongst its viewership. After the no-ads policy was established in 1981, the government lacked the necessary funding to produce programs that could attract viewers. This encouraged the government to allow commercial TV stations to operate. Such policy was directed to keep viewers from switching to foreign television, which they believed would endanger national stability (RemoTivi, 2014).

In the early 1990 s, private television stations started to emerge and until the end of the decade five private television stations established themselves: Rajawali Citra Televisi Indonesia (RCTI), Surya Citra Televisi (SCTV), Televisi Pendidikan Indonesia (TPI), Andalas Televisi (ANTV), and Indosiar. The first three were, at that time, a part of President Soeharto's business empire (Kartosapoetro, 2014). RCTI was owned by Bambang Trihatmodjo, Soeharto's third son, and TPI was owned by Siti Hardiyanti Rukmana, Soeharto's first-born. SCTV was owned by Henry Pribadi and Sudwikatmono, businessmen who were close friends with the Soeharto family. ANTV was and still is owned by Bakrie Group and Agung Laksono who held important positions in Soeharto's political party. Meanwhile, Indosiar was owned by Liem Sioe Lion's Salim Group which was within Soeharto's inner circle (RemoTivi, 2014).

In addition to its ruling position in the political sector, President Soeharto's family were also dominant in the business and economic sector. The family owned television and radio networks, chemical factories, shipping lines, pharmaceutical companies, banks, hotels, shopping malls, paper and pulp mills, and taxi companies. Those companies, along with companies owned by his close friends were given access to exclusive supply contracts, control of state-run monopolies, and special tax breaks during his 31 years in office (Sandbrook, 2016). In that period also, Soeharto and his family managed to reap between $\$ 15$ and $\$ 35$ billion from the state, which works out to between $\$ 480$ million and $\$ 1.13$ billion per year (Watson, 2014), making him the all-time most corrupt world leader in the world.

By 1998, the Soehartos' assets were estimated then to total $\$ 30$ billion, which would have ranked them among the world's dozen richest families (Shenon, 1998). Until later in the same year, the Asian Financial Crisis brought Indonesia to the brink of economic collapse. Students, political activists, and even common people started rioting and demanding that Soeharto step down from his presidency. He finally resigned from his position on 21 May 1998, ending the era of New Order.

This era of political and economic oligarchy inevitably shaped the Indonesian media system and culture. Media professionals were not used to disclosing any negative news regarding the government and journalists who were being too critical were found 'mysteriously' dead or thrown in jail (Sidharta, 2016). Indonesia's press freedom index was rated amongst the worst in the world by Reporters Without Borders (Reporters sans frontiers, RSF). It also made it physically dangerous for Indonesian press to conduct any governmentexposing investigative journalism practices. The press was also used to working in a culture where the owners of their company were tied to those who have political power and interests.

Since Soeharto's downfall, although the media is now able to report news without government constrictions, the practice of independent journalism in Indonesia continued to be obstructed by obstacles such as a weak legal system that does not always guarantee the rights of journalists, fear of lawsuits by wealthy and powerful individuals who would hide behind Indonesian 
criminal defamation law, which gives individuals leverage to sue journalists from exposing their ugly truths, including corruption, tax write-offs, etc. (Steele, 2011: 93), and threats of physical assault or personal attack from offended mobs (p. 85). The style of reporting also has not changed much: It often lacks full context and leans toward reporting on events instead of identifying any underlying causes (p.86). Newsrooms still believe that information is considered valid and more trustworthy when it comes from or is confirmed by government/public official sources (p.92).

\section{Media contents and its function as framer and agenda-setter}

According to Denis McQuail, there are several reasons why researchers study media content, one of these is to analyse and identify media bias. Intentionally or not, content of media is either always potentially open to the observation of favouring one side over another, or much of it has "...a clear direction of evaluation in relation to matters of dispute" (McQuail, 2010). Some of these researchers include Edward S. Herman and Noam Chomsky who coined the Propaganda Model of Mass Media in their book, Manufacturing Consent: The Political Economy of the Mass Media (1988). This model works within critical-Marxist tradition and basically argues that news discourses are created to serve some sort of propaganda function within capitalist, liberaldemocratic societies (Mullen \& Klaehn, 2010, p. 217). According to this model, there are five filter elements of news production processes.

"The five filter elements [of news production processes] are (1) the ownership, size and profit orientation of mainstream media; (2) advertising as the principle source of revenue for mainstream media and the corresponding influence of advertising values on news production processes; (3) mainstream media's routine reliance on agents of power as the primary definers of social reality; (4) organized flak that represents a mechanism of social control; and (5) various ideological forces, which may be deployed and adapted to correspond to elite interests when required (Mullen \& Klaehn, 2010, p. 218)."

These interests as mentioned by Mullen \& Klaehn are often reflected through one of the media's most prominent functions, which is its function as agenda setter. Walter Lippmann, a prominent American journalist, was one of the first writers to formalize the idea that media have the potential to structure issues for the public. He argues that as the real environment is too big and too complex for direct acquaintance, and people are not equipped to deal with so much subtlety and so much variety, therefore a simpler model is needed before we can manage with it, and that is what media offers. Stephen W. Littlejohn and Karen A. Foss state in their book Theories of Human Communication (2010), that scholars have described media's agendasetting as a function that establishes the relevant issues or images in the minds of the public.

Agenda-setting theoretically describes news media's ability to influence the importance of topics in the public agenda by frequently covering and reporting on it (McCombs \& Reynolds, 2002). For newspapers, it is easy to point out which stories hold the most importance: Lead story on the front page, the size of the headline font, the size of the column, and so on. In addition, once a story is printed on a newspaper, it stays there. It is a physical artefact. On the other hand, with television, a story will be gone from someone's attention once it has finished airing. Unlike a newspaper where people can read a story repeatedly and return to reference information, unless a viewer made an effort to record it, any information aired on TV cannot be repeated on demand. Therefore, television agenda setting has a more limited capacity. Which is why, time placement and frequency is the most effective ways to portray the saliency of a topic. The more urgent a story is considered, the more times it is repeated.

According to Littlejohn and Foss, citing Dietram A. Scheufele's work, agenda setting could be identified within two levels. The first one "...establishes the general issues that are important (object agenda setting), and the second determines the parts or aspects of those issues that are viewed as important (attribute agenda setting)" (p. 161). This article attempts to present an example of how this identification is applied by two different TV stations that were supporting two opposing politicians.

\section{Material and Methodology}

This work intends to answer the following question: how did the oligarchic ownership of the Indonesian news TV channels determine the ways in which such media covered two candidates who ran for president in 2014? Selecting the coverage by TV One and Metro TV as case studies, this research adopts the qualitative case study method as outlined by Cresswell (2014). The data were collected from reports and recorded broadcasts of these two channels from 1 June 2014 to 31 July 2014. The grounds for choosing this specific time frame are 
based on the time of the announcement of the presidential candidacy until the end of the campaign period. In addition, more data were obtained from academic and journalistic articles to support the analysis.

The data were analyzed using qualitativethematic content analysis method. As an independent qualitative descriptive approach, this method will be used to identify, analyze, and report patterns (themes) within the qualitative data in order to minimally organize and describe it in detail (Braun \& Clarke, 2013). According to Braun and Clarke, employing this method can be done through a sixstep process. These steps are (1) familiarizing the data, (2) generating initial codes, (3) searching for themes, (4) reviewing the themes, (5) defining and naming the themes, and (6) producing the report ( $\mathrm{p}$. 123). However, not all six steps will be elaborated upon in detail in this research as the collected data were already specific in nature. Instead, this research will review the already-defined data and explore it through the elaboration of the findings in the discussion part of this research.

\section{Result and Discussion}

1. Polarized national television news coverage of the 2014 presidential election Indonesian politics has effectively used multi-party system for decades. According to Indonesia's General Election Laws, number 422008, section three, article nine: in Indonesian multiparty election regulations, a party needs to win at least 20 percent of the seats in the House of Representatives, or win 25 percent of the popular vote in the legislative election to be able to nominate their presidential candidate (DPRRI, 2008). However, in the Indonesian 2014 Legislative Election, no single party gained above 20 percent of seats nor 25 percent of popular votes. The participating parties then formed two big opposing coalitions. Each coalition nominated a pair of Presidential and VP candidates. Koalisi Merah Putih, or Red and White Coalition, which consisted of Gerindra (Partai Gerakan Indonesia Raya/Great Indonesia Movement Party), Golkar (Partai Golongan Karya/The Party of the Functional Groups), PAN (Partai Amanat Nasional/National Mandate Party), Partai Demokrat (Democratic Party), PBB (Partai Bulan Bintang/Crescent Star Party), PKS (Partai Keadilan Sejahtera/Prosperous Justice Party), and PPP (Partai Persatuan Pembangunan/United Development Party) nominated Prabowo Subianto as Presidential candidate and Hatta Rajasa as VP candidate. On the other side, Koalisi Indonesia Hebat or the Great Indonesia Coalition, which consisted of PDIP (Partai Demokrasi Indonesia Perjuangan /Indonesian Democratic Party of Struggle), PKB (Partai Kebangkitan Bangsa/National Awakening Party), NasDem (Partai Nasional Demokrat/National Democratic Party), Hanura (Partai Hati Nurani Rakyat/People's Conscience Party), and PKPI (Partai Keadilan Persatuan Indonesia/Indonesian Justice and Unity Party) nominated Joko Widodo as Presidential candidate and Jusuf Kalla as the VP candidate.

The D-day of Indonesia's 2014 Presidential election was set for July $9^{\text {th }}$, 2014. The campaign period for Indonesia's 2014 presidential election started on June $4^{\text {th }}$ and ended on July $5^{\text {th }}, 2014$, but the names of the candidates had been announced by the KPU (Komisi Pemilihan Umum/General Elections Commission) on the $31^{\text {st }}$ of May that year. The first week alone after the announcement, political content had escalated in the frame of the media conglomeration from the month before.

According to an extensive research project by Remotivi, an Indonesian independent communication and media study, research, advocacy, and publishing centre, the number of news reports about politics broadcasted by 11 major Indonesian TV stations had multiplied by six compared to the previous month, from 512 to 3,305. Meanwhile, in regard to news revolving around the election, there were two particular stations with a notable imbalance when it came to reporting on the candidates. TV One's reports and coverage conspicuously and fervently rooted for presidential and VP candidates Prabowo-Hatta Rajasa, and Metro TV for Joko Widodo-Jusuf Kalla.

RemoTivi reported that during the first week of the campaign period, eighty percent of negative news broadcast by TV One was about Joko Widodo and twenty percent was about Jusuf Kalla. Twentyfive percent of the negative news about Joko Widodo were talking about campaign violation allegations, another twenty-five percent was regarding rumours about Joko Widodo's fake national identification card, another twenty-five percent about corruption issues, and the remaining twenty-five percent pertained to other negative news. On the other hand, fifty-two percent of the positive election news reports broadcast by the station were regarding Prabowo, and forty-four percent for Hatta Rajasa. Half of the news about Prabowo was regarding positive political survey trend, twenty-five percent 
about people's support for the candidate(s), and the remaining percentage was about other positive news.

During this period, Metro TV instead, broadcast zero negative news coverage on Joko Widodo-Jusuf Kalla, sixty-five percent on Prabowo and thirty-five percent on Hatta Rajasa. In the sixtyfive percent negative coverage on Prabowo, twentyfour percent were regarding the human rights violations, where Prabowo was accused of having orchestrated the abduction and torture of 23 democracy activists toward the end of President Suharto's rule in 1998. He was then a commander of the special forces, the military units allegedly conducting the abuses (Liljas, 2014). Furthermore, five percent of the negative coverage was on his proAmerican views, twenty-four percent on alleged campaign violations, ten percent regarding black campaign, and twenty-one percent was about alleged misuse of the national emblem. At the same time, the TV station broadcast only four percent positive news on Prabowo and Hatta Rajasa combined, while airing fifty-one percent positive news about Joko Widodo and forty-five percent about Jusuf Kalla. Fifty-nine percent of the positive news regarding Joko Widodo were about people's support towards the candidates, nine percent lauding his excellent work as a governor, eight percent regarding positive political survey trends, and twelve percent concerning positive profiling by experts (Arief, 2014).

Meanwhile, according to a survey conducted

by KPI (Komisi Penyiaran Indonesia/Indonesia Broadcasting Committee) during the second week of the campaign period, Metro TV aired news coverage on Widodo-Kalla 62 times, whereas the other candidates only 22 times. On the third week of the campaign period, TV One broadcast 153 news coverages on Prabowo-Rajasa and only 79 coverages on Widodo-Kalla. On the other hand, Metro TV aired 187 coverages on Widodo-Kalla, while ProbowoRajasa only got 110 coverages (Karana, 2014).

In addition to the unbalanced level of coverage provided by the two TV stations for the agenda of their preferred candidates, they also facilitated apparent black campaigns. Case in point, on June $30^{\text {th }} 2014$, TV One's morning talkshow program Dialog Kabar Pagi (Morning Dialogue) invited Retired Brigadier General Priyanto, former Deputy Governor of Jakarta and former Territorial Assistant to the Indonesian Army Chief of Staff. The segment was discussing a resurgence of communism and how much it could threaten national security. As an informant, Priyanto implied that PDIP had sent their people to China to learn from the Chinese
Communist Party and that their presidential candidate, Joko Widodo, supported communism (Dasman, 2014). The TV station did not invite any representative from the opposing side, making the news segment appear to be extremely biased. The two stations also framed a news coverage differently for each candidate. When TV One broadcast a report regarding Prabowo and Hatta Rajasa, they paired it with a banner reading "Presiden Pilihan Rakyat (President of People's Choice)," whereas they only labelled news regarding Joko Widodo and Jusuf Kalla as "Calon Presiden (Presidential Candidate)." On the other hand, when Metro TV aired a coverage about Prabowo-Rajasa, they tagged it simply as "Presidential Candidate," but tagged Widodo-Kalla as "Presiden Pilihan Kita (President of Our Choice)" (Herawati, 2016).

The polarized media coverage kept going on until the election was over. As reported by Bisnis.com, by 6 p.m. local time on July $9^{\text {th }} 2014$, TV One declared that Prabowo-Rajasa won the quick count vote. However, according to the candidate's spokesman, they wanted to wait until at least ninety percent of the votes were counted before announcing their victory. At the same time, Metro TV had already announced Widodo-Kalla's quick count victory. Widodo even made a statement where he thanked the people who had voted for him and all his supporters (Adlin, 2014). Eventually, on July 22 ${ }^{\text {nd }}$ 2014 the National Election Committee announced that Joko Widodo officially won the election by 6.3 percent margin over Prabowo and he was to be inaugurated on October $20^{\text {th }} 2014$.

\section{Indonesian Media System and How It Sets Agendas and Frames News for the Oligarchs}

When TV One broadcast news coverage on Prabowo 153 times within a week compared to 79 times on Widodo-Kalla, the station intended to convince its viewers that in this election, Prabowo was more important than Widodo. Likewise, Metro TV's decision to broadcast 187 news coverages on Widodo-Kalla while only giving 110 for ProbowoRajasa meant to posit that Widodo-Kalla is the more important topic in viewers agenda and in the context of the Presidential Election compared with PrabowoRajasa.

The first level of agenda setting establishes the general issues that are important, and the second determines the parts or aspects of the issues that make it important (Littlejohn \& Foss, 2008, p. 293). This second level of agenda setting is also known as 
framing. Media framing is necessary in the process of mass media reporting. Media depictions frame events by various textual features of the "story" such as headlines, audio-visual components, use of metaphors, the way in which the story is told, and many others. These ways were expected to constrain how the audience can interpret these events (p.294). For instance, by using the label "President of People's Choice" to address Prabowo and "President of Our Choice" to address Joko Widodo, TV One and Metro TV were framing their respective candidates as someone that should be chosen as the president. Littlejohn and Foss also consider that media agenda is established by some combination of internal programming, editorial and managerial decisions, as well as external influences from non-media sources such as socially influential individuals, government officials, and commercial sponsors. But what was the actual factor or reason that influenced TV One to prioritize Prabowo and Metro TV to prioritize Widodo in their respective agendas?

In Indonesia's media scene, owners of major media companies are often directly affiliated with political parties. There are currently 14 national television stations operating in Indonesia. Four of them, RCTI (Rajawali Citra Televisi Indonesia), MNCTV (previously TPI or Televisi Pendidikan Indonesia), Global $\mathrm{TV}$, and iNews $\mathrm{TV}$, belong to MNC Group. This giant media corporation is owned by Hary Tanoesoedibjo, a billionaire businessman who has also been involved in national politics as a former member of Nasdem, before joining Hanura, and now has founded his own political party, Partai

Persatuan Indonesia/Indonesian Unity Party (Perindo) (Brown, 2017).

Another example of affiliation between media and political figures is the case of TV One and Metro TV. Metro TV, established in November 2000 , offered a news-oriented broadcasting concept. It is also the first Indonesian national TV station that broadcasts 24 hours non-stop, and the only station that does not air soap opera programs. Metro TV is operated under Media Group, a media holding owned by Surya Paloh, a former member of the Golkar advisory board, before chairing Nasdem in 2013 until present. In the Indonesia's 2014 Presidential Election, Nasdem was one of the parties in the Great Indonesia Coalition, a coalition supporting Joko Widodo and Jusuf Kalla. TV One is instead, owned by Visi Media Asia, Ltd., along with Andalas Televisi (ANTV). Visi Media Asia is a subsidiary of Bakrie Global Ventura of Bakrie Group, a large holding company owned by Aburizal
Bakrie, former Coordinating Minister of Economy, former Coordinating Minister for People's Welfare, and current Chairman of Golkar (Jegho, 2015). As a matter of fact, Golkar was one of the member parties which supported Prabowo-Hatta Rajasa in Red and White Coalition. Paloh and Bakrie used their power as the owners of their respective media companies to set their agenda: to portray the candidates they supported as someone worth voting for and the opposing candidates as a failure. Therefore, TV One chose to broadcast negative news on Widodo-Kalla and positive news on Prabowo-Rajasa, and on the other hand, Metro TV focused on Widodo-Kalla's achievements and supports while showing PrabowoRajasa's weaknesses.

These media owners did not even try to be subtle in using their media companies for their political agenda. Between March and July 2008, Indonesian book author and mass-communication expert, Ignatius Haryanto, conducted a research on the impact of concentrated media ownership on journalism practice. Haryanto interviewed four working journalists from different media groups, with one of them being a running text reporter at Metro TV. This informant attested that Surya Paloh did not shy away from using his media to advance his political and economic interests. Paloh also openly stated that he "...used Metro TV and Media Indonesia as his political vehicle, declaring "if I can't use them, what else can I use? If there are any journalists who disagree with this situation, they are free to leave Metro or Media Indonesia. I don't want to be hypocritical"' (Harsono, 2004 in Haryanto, 2009, p. 111).

Following the ideas of Robison and Hadiz, Tapsell $(2015$, p. 31$)$ argued that such embodiment of media control indicates one of the crucial elements that constitute an oligarchy. Oligarchic media owners generally shape news and information according to their wishes (Tapsell, 2015, p. 34). In his article Indonesia's Media Oligarchy and the Jokowi Phenomenon, he explains that many scholars have concluded that Indonesian media today is largely operating in a free market-driven environment, where audience and readership heavily determines what and how news is produced. However, he also states that at the same time, there has been an "...increasing concentration as well as on the role that powerful owners play in limiting information" (Tapsell, 2015, p. 34).

Stefaan Walgrave and Peter Van Aelst (2006 cited in Littlejohn \& Foss, 2008, p. 294) mention that the power of media to affect the public depends on 
various factors, such as “...media credibility on particular issues at particular times, the extent of conflicting evidence as perceived by individual members of the public, the extent to which individuals share media values at certain times, and the public's need for guidance." In the case of Indonesian readership, or rather viewership, deeply rooted oligarchic culture within Indonesian media professionals led to similar mentality amongst Indonesian audiences. According to many scholars such as Phillip Kitley (2000) and Mark Hobart (2006), it was Indonesian people's "obsession" with analog television that prompted oligarchic control of the media in the first place. It currently " ... dominates the media market, being the medium with the most reach and popularity." Even in 2014, with more access to cable TV and internet, television, along with newspaper, was still considered the main source of information for Indonesians, especially those who were not familiar with cable $\mathrm{TV}$ and internet (Tapsell, 2015, pp. 31-32).

For decades, television has been the primary source of information and entertainment for Indonesians, with a government-controlled channel being the only option they had. They had been taught, or more likely indoctrinated, to believe that everything they see on television is true, valid, and legitimate. They had never been given alternative information, making them used to seeing things from limited perspective. These factors have moulded Indonesian viewers to become complacent and uncritical when it comes to information. They had learned not to second-guess, especially information about and/or obtained from government officials. Even by January 2016, only 4.6 percent of Indonesian households had access to cable TV (Wulandari, 2016) which offers more options of programs, including international news that could potentially set a different standard and perspective on news quality. Which is why, people with positions of power in this oligarchic media system take advantage of the situation by easily "feeding" the public with information that suits their own interests. Although, later on, free market national television post-New Order era overwhelmed Indonesians with a wide range of entertainment choices such as sports, foreign films and shows, soap operas, and cable television, Indonesian audience have never had the chance to receive proper education on media literacy.

\section{Conclusion}

The polarization of TV One and Metro TV coverage in reporting news on the Indonesia 2014
Presidential Election candidates was a result of the oligarchic media ownership over the two TV stations. As the respective owners of both TV stations were also involved in the parties which were backing the candidates, they used their media companies to deliver their personal political agendas in the hope that it would influence or even set the public's agenda. Now there has been no proof that Joko Widodo's victory was a direct result of Metro TV's successful agenda-setting attempts. However, the competition between the two stations in supporting their favourite candidate was reflected in the result of the election where the votes were split by a very thin margin. When compared to the following presidential election in 2019 through a review written for Asian Politics \& Policy by Nyarwi Ahmad (2019), it can be generally concluded that the polarization was still present. However, instead of focusing on the candidates' personal 'dirt', the media polarization throughout the 2019 presidential election focused on identity politics and religion (Ahmad, 2019). This could potentially be an interesting topic to be explored more in future research.

Oligarchic culture has existed for too long and runs too deep within Indonesian media system, including television. It has shaped the way in which Indonesian media operate and practice their functions in the society. It also has moulded Indonesian viewers' mindset to never question the truth or anything beyond what is conveyed by the media, even now when they are presented with a wide variety of programs and channels. It is a win situation for media owners, advertisers, their political collaborators, or anyone who might want to easily shape the public's mind. But it is a definite loss for Indonesian viewers who deserve media that holds their best interest as its priority.

\section{References}

Adlin, E., (2014). Quick Count Pilpres 2014: Prabowo Unggul di TV One, Jokowi Menang di Metro $\quad T V$ [Online] Available at: http://bali.bisnis.com/read/20140709/74/4599 1/quick-count-pilpres-2014-prabowo-unggul-diTV One-jokowi-menang-di-Metro TV [Accessed 7 June 2017].

Ahmad, N., (2019). Indonesian News TV Channels and Polarized Political Issues. Asian Politics \& Policy, 11 (3): 505-519.

Arief, Y., (2014). Independensi Televisi Menjelang Pemilu Presiden 2014: Ketika Media Jadi Corong Kepentingan Politik Pemilik (Bagian 3) 
(Television Independenc in During 2014 Presidential Election: When Medias Becomes Owner's Political Megaphone (Part 3), Jakarta: Remotivi.

Clarke, V. and Braun, V., (2013). Teaching thematic analysis: Overcoming challenges and developing strategies for effective learning. The psychologist, 26(2): 120-123.

Brown, A., (2017). Meet The Donald Trump of Indonesia: Another Billionaire Who Wants to be President. [Online] Available at: https://www.forbes.com/sites/abrambrown/20 17/03/20/donald-trump-hary-tanoesoedibjoindonesia/\#68c82a3a50b1 [Accessed 8 June 2017].

Cresswell, J.W. (2014). Research Design: Qualitative, Quantitative and Mixed Methods Approaches. London: Sage Publication.

Dasman, B., (2014). Bermula dari Prijanto. [Online] Available

at: http://kupang.tribunnews.com/2014/07/04/ber mula-dari-prijanto [Accessed 7 June 2017].

DPRRI, (2008). Undang Undang Republik Indonesia Nomor 42 Tahun 2008. [Online] Available at: http://www.dpr.go.id/dokjdih/document/uu/U U 2008 42.pdf [Accessed 6 June 2017].

Herawati, E., (2016). Mengevaluasi Jurnalisme Media Televisi pada Pemilu (Evaluating Television Journalism in General Election). [Online] Available at: http://businesslaw.binus.ac.id/2016/12/29/mengevaluasijurnalisme-media-telivisi-padapemilu/ [Accessed 7 June 2017].

Idrus, P. G., (2018). LIPI: Publik Ikuti Berita di TV, Pemuda Pilih Medsos. [Online] Available at: https://www.aa.com.tr/id/headline-hari/lipipublik-ikuti-berita-politik-di-tv-pemuda-pilihmedsos/1208224 [Accessed 16 September 2019]

Jegho, L., (2015). Aburizal Bakrie Regains Golkar Chairmanship. [Online] Available at: http://www.globalindonesianvoices.com/2081 7/aburizal-bakrie-regains-golkarchairmanship/ [Accessed 8 June 2017].

Karana, P., (2014). Pilpres 2014: Ketika Media Jadi Corong Propaganda (2014 Election: When Media Besomes the Megaphone of Propaganda). [Online] Available

at: http://www.bbc.com/indonesia/berita indones ia/2014/07/140702 lapsus media bias [Accesse d 7 June 2017].

Kartosapoetro, I. S. (2014). Media dan kekuasaan: televisi di hari-hari terakhir Presiden Soeharto. Jakarta: Penerbit Buku Kompas.
KPI, (2012). Pedoman Perilaku dan Standar Program Siaran (Broadcasting Practice Guidance and Broadcasting Program Regulation). [Online] Available

at: https://denpasarkota.go.id/assets_subdomain/ 63/download/P3SPS\%20KPI_089566.pdf [Acces sed 9 June 2017].

Littlejohn, S. W., \& Foss, K. A. (2010). Theories of human communication. $10^{\text {th }}$ ed. Long Grove: Waveland press.

McCombs, M. E. \& Reynolds, A., (2002). News influence on our pictures of the world. In: J. Bryant \& M. B. Oliver, eds. 2009. Media effects: Advances in theory and research. New York: Routledge.

McQuail, D., (2010). Mass Communication Theory. London: SAGE Publications Ltd..

Mullen, A. \& Klaehn, J., (2010). The HermanChomsky Propaganda Model: A Critical Approach to Analysing Mass Media Behaviour. Sociology Compass: 215-229.

RemoTivi, (2014). Membaca Gerak Industri Televisi (Reading the Movement of Television Industry). [Online] Available at: http://www.remotivi.or.id/amatan/37/Membac a-Gerak-Industri-Televisi [Accessed 7 June 2017].

Sandbrook, J., (2016). The 10 Most Corrupt World Leaders of Recent History. [Online] Available at: http://integritas360.org/2016/07/10-mostcorrupt-world-leaders/ [Accessed 7 June 2017].

Shenon, P., (1998). The Suharto Billions - A special report: For Asian Nation's First Family, Financial Empire is in Peril. [Online] Available at: http://www.nytimes.com/1998/01/16/business /suharto-billions-special-report-for-asian-nations-first-family-financial-empire.html [Accessed 7 June 2017].

Shoemaker, P. J., Vos, T. P. \& Reese, S. D., (2009). Journalists as Gatekeepers. In: J. Bryant \& M. B. Oliver, eds. The Handbook of Journalism Studies. New York: Routledge.

Sidharta, J., (2016). Evolution of Press Freedom in Indonesia. [Online] Available at: http://www.globalindonesianvoices.com/2492 4/evolution-of-press-freedom-inindonesia/ [Accessed 7 June 2017].

Steele, J., (2011). Indonesian Journalism PostSoeharto. In: K. Sen \& D. Hill, eds. Politics and the Media in Twenty-First Century Indonesia. London: Taylor and Francis: 85-103.

Stetka, V., (2016). The rise of the oligarchs: the third media ownership transformation in CEE. 
[Online] Available at: https://www.unimuenster.de/Jura.tkr/oer/files/pdf/workshops/201 6/impact on media systems/Stetka.pdf [Access ed 4 September 2019].

Tapsell, R., (2015). Indonesia's Media Oligarchy and the "Jokowi Phenomenon". Indonesia, Issue 99: $29-50$.

Utomo, W. P., (2017). Oligarki media dan bagaimana dia menentukan arah pemberita an. [Online] Available at: http://theconversation.com/oligarki-mediadan-bagaimana-dia-menentukan-arahpemberitaan-86639.

Watson, B., (2014). Six of the Most Absurdly Corrupt Leaders in Recent Memory. [Online] Available at: http://www.esquire.com/newspolitics/news/a28723/corrupt-leaders/ [Accessed 7 June 2017].

Winters, J. A. (2011). Oligarchy. New York: Cambridge University Press.

Worth, O. (2017). Hegemony, International Political Economy and Post-Communist Russia. $2^{\text {nd }}$ ed. Farnham: Ashgate

Wulandari, D., (2016). Pertarungan di Pasar TV Berbayar (Competition in Paid Television Market).

[Online] Available at: http://mix.co.id/headline/pertarungan-dipasar-tv-berbayar [Accessed 8 June 2017]. 